\title{
Problems of Assimilation and Difficulties of Becoming a Man in LeRoi Jones's Dutchman
}

\author{
Madhav Prasad Dahal ${ }^{*}$
}

\begin{abstract}
This article attempts to explore the obstacles of an African American in becoming a Man in the white community in LeRoi Jones's play Dutchman. In doing so, it analyzes the text from African American perspective, which is a black cosmological lens applied to critically examine African American history, culture and the literature, primarily with its focus on cultural assimilation and its aftermath . LeRoi Jones, also known with his new name Amiri Baraka, in this play exposes how the black Americans fall victim of racial hatred in the process of assimilating themselves with the mainstream white ways of life. The major argument of this article is an African American's process of assimilation with the white culture is not only a detachment from his/her origin but also his/her failure to be accepted by the new culture. It argues that in adopting a new culture, a colored American is twice the victim of his/her past and the present. To justify this stark predicament of colored American population, the article briefly looks back at the situation of the American blacks in the 1960s. It ponders on the entire behavior of Clay, a twenty years old black boy in the play, his fondness in choosing to imitate the white world as a model. His craze for white way of life is reflected in the dress up he is putting on, his mastery over the use of cosmetic language of the whites, his eating of apple given by Lula, a thirty years old white lady who morbidly tempts him for sexual intercourse, his attempt to forget his own ancestral history to make him look more like an American than a descendent of slave. The article also analyses Lula's stereotyping of Clay and the way she dictates white values and norms.
\end{abstract}

Keywords: man, cosmological, detachment, assimilation, racism, slave

\section{Introduction}

Among all the immigrants to the US, the story of African immigrants is different. Many of them were forcibly brought to the United States as the slaves. Those who migrated with their own will to get employment opportunities were also paid off less in

${ }^{*}$ Mr. Dahal is Lecturer in English at Mahendra Multiple Campus, Dang, Tribhuvan University, Nepal. 
comparison to the migrants of white color. The studies have shown that the wages between the black and white migrants are different. Observing the 1990 census of the US, Dodoo and Takyi (2002) found that hourly wages of 25 to 64 years old African origin white male migrants are $32 \%$ higher than those of comparable black migrants. After they migrated to the US for whatever reason, it was their compulsion to forget their ancestral line and to learn the white ways of life. On the one hand, the memory of their origin hit them. Larry J. Griffin and Peggy G. Hargis (2008) expose this fact in these lines thus: "The past reminds - makes- us who we are and, sometimes when we acknowledge that past, it also makes us wish we were not who we are" (p, 42). However there was no way out to return to their home land, and on the other hand, assimilating with the new culture was not easy. The color line between the two races could not allow the whites to accept the blacks as their brothers and sisters. They could not keep the blacks a little above the rank of slaves. Every attempt of the blacks in the direction of assimilating them with white culture was not only a subject of mockery but also an intolerable phenomenon for the whites.

Le Roy Jones's play Dutchman can be seen as a representation of the situation of the black during the 1960s. It was a decade that was unprecedented in history. The black Americans demanded equal treatment and massively resisted segregation. Leland Ware (2013) says, "By the end of the decade federal legislation outlawed the practices that had been used to reduce African Americans to second-class status" (p.10). The 1964 Civil Rights Act, Voting rights of 1965 and the 1968 Fair Housing Act had given the American Negroes strength to resist further. The Play Dutchman had come at such times of renaissance. But there was still a racial mountain even after the law had guaranteed Blacks equality. They were facing integration problems. Quoting LeRoi Jones, MacNicholas (1981) says, "Dutchman is about the difficulty of becoming a man in America" (p. 53). It gives a picture of the predicament of the American blacks during that time. Berkowitz (1992) states that racism as the previous condition was living death...so black people were faced with two alternatives, assimilation or revolt. They had to find new identities (p. 146). The play Dutchman exposes the male protagonist Clay as the one who has chosen the first one. By doing so, he seems to have detached him from his ancestral culture and origin. He does so hoping that he would have a distinct identity in his society that the world of white would appreciate and accept regarding him as its own member. He takes the white world as a model which is reflected in his appearance, language (his mastery of language gives him access to the white world (Bigsby, 1985, p.397). But his expectations are derailed in an insulting way that he becomes a bare life in the land of opportunities. He is behaved like a homo sacer in his process of being a man. He is a representative of not only the African Americans but also of all who are struggling to make an individual identity of a 'Man' in the US. 
The word 'man', in African American studies, implies a strong masculine, a bold bread earner, who is courageous, handsome, and fashionable and can reflect the American ways in his entire ways of life. Clay exposes the fact that due to a visible racial biasness towards the blacks the chances of climbing the ladder of progress in America through the assimilation of the self with the white way of life is not that much easy. And moreover, it is quite difficult for the blacks to be treated with respect as the American citizens because the racial mountain between the black and the white is quite high and they are taken by whites as savage and worthy to be mocked. In this context of wider cultural gap, this paper attempts to explore those difficulties that an African American faces in culturally assimilating himself and making him a 'Man' in the new world.

Dutchman has received scholarly and critical attention from different critics. After the emergence of the postmodernist theories in the 1960s the new modes of interpretations emerged. The deconstructionist way of interpretation sees indeterminacy in the way Lula presents her. Jonathan Cooler (1982) says,, "A Derridean would agree that the language game is played but might go on to point out that one can never be quite certain, who is playing, or who is playing seriously, what the rules are, or which game is being played" (p.130-131). In Dutchman Lula is seen as an indeterminate character. She presents herself as an indeterminate one as for her 'being' is a form of playing a game. She keeps on changing position as a modern woman or a white stereotype. Kimberly W. Benston (1976), in her comprehensive study of LeRoi Jones's work, Baraka: The Renegade and the Mask, points out in the action of the play in the tragic pattern: "the fall from innocence through hamartia, and from hamartia to catastrophe" (p.158). She traces the classic tragic pattern in Clay's fall. The departure of this study with these concerns of the critics is that this paper, different from other theoretical imaginings and the set patterns, focuses on the real everyday problems of the African Americans in their processes of assimilation and becoming a man.

Textual Analysis

Dutchman was first released at the Cherry Lane Theatre in 1964 in New York. It gained Obie-Award and was then made into a film in 1967. Just after its release the play received dual commentaries as it was performed for dual audiences. It was both praised and criticized at the same time. It was interpreted as a play that hated the white community. Bisbee says, "After all it incited indignation because of being interpreted as a white- hating play with its radical language and its racist attitude against the white people" (p. 375). It was natural for the white community to perceive the play as the one that pours out black bitterness against them. But there in the white people's world there were also people who grasped just the other part of the play different from the white people. For them the play carried with it several other social issues as MacNicolus (1981) says, "It is about the racial betrayal, anti racist sentiments and black 
consciousness raising combined with gender and class themes" (p. 51). Furthermore it is about American history (Bloom, 1995, p.89). Bigsby says, "The play describes Baraka's own autobiography in which he asks the general question of personal identity and the nature of the relationship between the self and the society (p. 397). These observations show that the play is interwoven with varieties of themes. As the focus of this study is about how a black faces difficulties on the way to his self formation, it seeks to explore these issues in the text.

\section{Clay: His Past and Present}

The name 'Clay' comes from the Biblical reference. It reminds us of the image of the fallen Adam for his sin. Adam was made of dust, or clay. The play in this sense can be interpreted as a political allegory. Annette Saddik (2006) says, "Dutchman is a metaphor for a cycle that is repeated endlessly throughout history; it is a political allegory of race relations in America" (p.75). It depicts the hostile relationship between the whites and the black people. Clay is a black representing black people's spirit. His name is associated with the resurrection of Adam. He is an educated, high spirited and flexible person who easily falls in the honey trap of Lula. As Eve in the Bible convinced Adam to eat the apple, here Lula feeds the apple to Clay. This ultimately sets a ground for his fall. But unlike Eve in the Bible, Lula does not fall; she herself kills Clay keeping herself in the position of his boss.

LeRoi Jones wants to show that Clay is a representation of all humanity. But Lula takes him as a malleable creature born and grown up out of gutter or as Adam thrown out of heaven. In the play Clay is the representative of black community. He comes from a slave family heritage. In the eyes of white he is a savage; he is neither educated nor civilized at all. According to Lula, his grandfather was a slave; he did not go to Harvard. He himself says, "My father was a night watchman" (Baraka, 1964, 512). Lula says, "You went to colored college where everybody thought they were Averell Harriman" (Jones, 2005, 2512). He is labeled as the son of a slave whatever position he has acquired now. Whatever family line or the spatial connection, Clay desired to be treated as a respectable individual. Michell Wallallace (1978) says, "Clay wanted freedom, equality and all that. But what he really wanted was to become a 'man' (p. 30). He wanted to have his identity as a man who can make a pursuit of his own happiness. He believed that anyone had a right and a chance to earn the highest level of material or spiritual success in the American land.

As Robinson (2000) says the black people living in America were not meant to be pliant captives and agents of institutions that denied light all over the world. They had to speak the truth to themselves and to the community and to all who invited them into new darkness. They had to affirm the light, the light movement of the past, the light 
movement of their people. They had to affirm their capacities to move forward towards new alternatives for light in America. (p. 3). Clay wanted his masculinity to provide him a chance to make love with Lula. For this he had modeled himself according to the demand of the land and its culture. He had put on a three button suit, he had a book on his hand to prove that he was not an illiterate; he had learnt the polished way of speaking white English. He could dance in the way the whites do. But all these attempts of making him an American man are just his fantasies that are not going to get fulfilled. His endeavors to assimilate himself with his model culture become an irony of his fate. He is like a pendulum moving to reach nowhere. He is twice betrayed and traumatized, the first by the detachment from his ancestral culture, and the second by the culture he wants to assimilate with. He is dislocated. The most dramatic moment occurs when Clay throws off or breaks out of his false white man's self. He realizes the difference between his true identity and the false masking of a white persona. Lula tells him,

Why are you wearing a jacket and tie like that? Did you people ever burn witches or start revolutions over the price of tea? Boy, those narrow shoulder clothes come from a tradition you ought to feel oppressed by. A three button suit. What right do you have to be wearing a three button suit and a striped tie?" (Jones, 2512).

Lula's reaction at Clay wearing a three buttoned suit reflects how difficult the situation of a black is in becoming an American man. His buttoned up dress up in the white convention to make him an American man keeping him away from white vengeance gets loosened by Lula's words.

\section{Lula, the Apple and the Stereotyping of the Blacks}

Lula is a symbolic character in the play Dutchman. She symbolizes White America. She achieves her end through the use of apples. When she enters the subway car and takes her seat next to Clay, she seductively cuts the apple and starts devouring it. She tells Clay to eat it. This reminds us of the Biblical story of Eve who tempts Adam to taste the fruit of knowledge forbidden by God. The apple is a tool for Lula to seek out her victim for her ritual drama of love and death in this play Dutchman. She looks like the bringer of people's destiny. She often rides on the subway vehicle to trap someone. Lula gives us the image of a betrayer who caresses Clay's thigh but the level of her repulsion for the black color boils over. She, as the owner of American land intends to drive Clay out forcing him to sin by eating the apple. Not only uses the apple, she uses many other strategies to tempt her victims. Her voice is coarse and a "gentle sidewalk throb". Her hands are "dry as ashes". Her hair, the glass, the loud lipstick and the language tempt anyone coming across her. She takes her conversation to pure sex talk. "I am prepared for anything. How about you? (Jones, 2506). She lures Clay saying "you tried to make it with your sister when you were ten...But I succeeded a few 
weeks" (Jones, 2507). This looks like her unconscious erotic desire to make Clay her phallic partner. The difference between her age and Clay's is ten years.

Kimberly Benston suggests that, as the "white temptress [Lula] is [also] a composite of many seductress, Circo, Calypso, Dido, Cleotraptra, Duessa, Delilah- but she specially resembles Eve" (p.158). But outside this mask of her persona, apparent racism dwells. She warns Clay in the way he cannot comprehend her straight. She says he is a "well known type" (Jones, 2509). She stereotypes Clay in every conversation with her. She pretends like knowing nothing about him but she knows everything. This reminds us of George Orwell's Big Brother of the novel 1984, seeing and knowing everyone. Williams (1978) regards her as the "prototype of the white hipster who presumes to know Black people and their culture better than Black people know it themselves" (p. 137-38). When Clay asks Lula about his friends, she says, "I told you I lie. I don't know your sister. I don't know Warren Enright (Jones, 2507). But a little later she says, "Is Warren Enright a tall skinny black boy with phony English?" (Jones, 2507). It shows that she knows them all. Louis Casimir Jr. (1974) has called her "Medusa- like Creature" with links to the Loathly Lady of Chaucer's Wife of Bath's Tale (p. 303). Lula is therefore seen like the Biblical "The Strange Woman who, according to Claudia Camp (1997) will lead unwary youth to death through deceptive language which entraps him in sexual misconduct, typically adultery that violates his ethically upright life" (p. 85-112). She is not only a white lady but also a representative of the whole white America.

Nita K. Kumar (2003) in his article "The Logic of Retribution" says, "Lula's sense of her own identity, her perception of Clay is a series of stereotyped images... She evokes every stereotype that has historically defined the African American, from the escaped slave to Uncle Tom (p. 227). She uses quite condemning and stereotyping words like 'fascist', ' murderer', " escaped nigger" to Clay to keep control over him. She characterizes him as either guilty or fake, with little possibility of an authentic existence (p. 227). She is so hypocritical that she accuses Clay for gazing at her leg from the window of the subway car-"Weren't you staring at me through the window?

... I guess you were just taking those idle potshots. Nothing else to do. Run your mind to people's flesh ( Jones, 2506). It was all her stereotyped assumption and pretence to blame that black people are savage.

Lula represents a repugnant white society which the blacks like Clay should not embrace. She hates Clay not only because he is black in color, it is because he shows an obvious attempt of assimilating with the white culture discarding his own heritage. However the irony is that the blacks are compelled to struggle in making themselves melted in the White way of life by sacrificing their own original identity in the land where they are mucked, subjugated and even demonized. Clay faces the tragic fate of 
falling from his desire of assimilating that has only distanced him from his own heritage. He is compelled to allow Lula to take decisions about his life as he is not able to manage his life as per his own desire and because he is always under the white control. Though he tries to oppose her bullying at some time, he feels remaining non resistant is the safest way to go. In his submissiveness he discards his desire of going against the white hegemony. He realizes that walking a different way than this might rather be terribly disastrous. His passive endurance of Lula's verbal attack against him inevitably leads him to the mouth of death. His cultural upbringing of not resisting the white with a further terrible outcome makes him a tragic 'type'. As Amiri Baraka said in an interview Conversation with Amiri Baraka, "Clay's tragic fall is his passivity; he should be resisting that type of murder. Clay commits the crime that Baraka ... condemned black artists for committing: being content to cultivate any mediocrity, was guaranteed to prove to America ... that they were not really who they were, i.e. Negroes" (Saddik, 74).

Not only Clay, the other black passengers traveling in the same subway car also witness Clay's murder. They could have protested Lula for stabbing Clay and even taken revenge against her but they simply watch the event without a word of protest. Not only that they also silently obey Lula when she orders them to throw Clay's dead body out of the moving car. As Lula shouts at them to get off the car at the next stop, all of them do accordingly. The conductor, who could also have captured Lula or disobeyed her, remained silent. The next black boy who rides on the subway train just after Clay's murder was also quite young enough to fight against Lula. But Lula passes an evil look towards him as her next victim. He too, simply shows his docile smile to her villainy. The justice would have been there if this new rider had killed a murderer of the innocent boy. But their powerlessness deprives the blacks from going against the whites. As the title of this play 'Dutchman' comes from the biblical allusion of a flying Dutchman killing hundreds of people behind, the play here shows the serial murder of black Americans by the white members just to subjugate the blacks. The ship alludes to the Dutch vessels that transported slaves to the New World and the legend to the Flying Dutchman, a ghost ship doomed to sail forever as retribution for the crimes of its crew (Baker, 110).

\section{Conclusion}

Dutchman thus records the difficulties of the blacks in the process of establishing their identities. The dominant issue at the heart of this play is the idea of black people's struggle for their socially distinct identity in the American land and the way they are suppressed by the whites just due to their race there. It deals with how the American Negroes face problems in the process of converting themselves in the way the White world does. It shows they can neither survive respectfully there as Americans nor as 
Africans. The reason behind such humiliation is nothing other than the color of their skin. By means of Clay as the black stereotype the play portrays the black people's repressed feelings of anger and a desire of a revolution to force the whites to accept them socially and culturally. It also reflects how the black community is double agonized by the loss of their original heritage and by the rejection of the new culture. These arguments now bring me to the conclusion that the play Dutchman is about the problems of assimilation and the difficulties of becoming a man in America.

\section{References}

Baker, C. (2013). A trip with the strange woman: Amiri Baraka's "Dutchman" and the book of proverbs. South Atlantic Review, Vol.78, No.3/4, pp. 110-128.

Baraka, A. (1964). Dutchman and the slave: Two plays by LeRoy Jones. New York: Harper Perrenial.

Benston, K. W. (1976). Baraka: The renegade and the mask. London: Yale University Press.

Berkowitz, G. M. (1992). American drama of the twentieth century. London: Longman, p.53.

Bigsby, C. W. E. (1985). A critical introduction to twentieth century American drama. Vol.3, Cambridge: Cambridge University Press, p. 375.

Bloom, C. (Ed.) (1995). American drama. Stuttgart: Macmillan Press CDD.

Camp, C. V. (1997). "Woman wisdom and strange woman: Where is power to be found". Reading Bibles, writing bodies: Identity and the book. Ed. Timothy K.et al. Abingdon: Rutledge, pp. 85-112.

Casmir, Louis Jr. (1974). "Dutchman: The price of culture is a lie". The binding of Porteus: Perspective on myth and the literary process. Ed. Marjorie W. McCure, et al. Pennsylvania: Bucknell UP, pp. 298-310.

Culler, J. (1982). On deconstruction. Abingdon: Rutledge.

Dodoo F.N-A, and B. K. Takyi. (2002). Africans in the diaspora: black-white earnings differences among America's Africans. Ethnic and Racial Studies, Vol. 25, Issue 6, 913-941.

Griffin, L., \& Hargis, P. (2008). Surveying memory: The past in black and white. The Southern Literary Journal, Vol.40, Issue 2, pp. 42-69. Retrieved October 11.

Jones, L. (2005). "Dutchman". Heath anthology of American literature. Paul Lauter (Ed.), Vol.5, ed.5, Boston: Houton Miffin.

Kumar, N. K. (2003). "The logic of retribution". African American review. Vol.37, no, 2/3, Amiri Baraka Issue, (Summer- Autumn), United States: John Hopkins University Press. 
MacNicholas, J. (1981). Dictionary of literary biography, Vol. 7: Twentieth century American dramatists part 1: A-J. Gale Research Company, p. 51.

Robinson, C. J. (2000). Black Marxism: The making of black radical tradition. The University of North Corolina Press.

Saddik, A. J. (2006). Contemporary American Drama. Edinburg University Press, 2007, pp. 73-76. http://www. Encyclopedia.com/arts/educational magazines/dutchman

Wallace, M. (1978). Black macho and the myth of superwoman. London: Verso.

Ware, L. (2013). Civil rights and the 1960s: A decade of unparalleled progress. Maryland Law Review, Vol.72, Iss.4, http://digitalcommons.law.umaryand.edu/mlr/vol72/iss4/4.

Williams, S. A. (1978). "The search for identity in Baraka's Dutchman”, Imamu Amiri Baraka (LeRoi Jones): A Collection of Critical Essays. Ed. Kimberly W Benston, United States: Prentice Hall, pp. 135. 